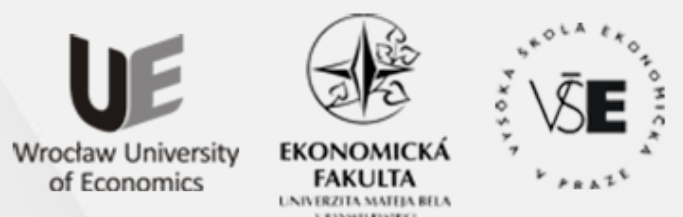

Conference Proceedings

Full TeXT PAPERS

edited by

Zofia Rusnak and Beata Zmyślona

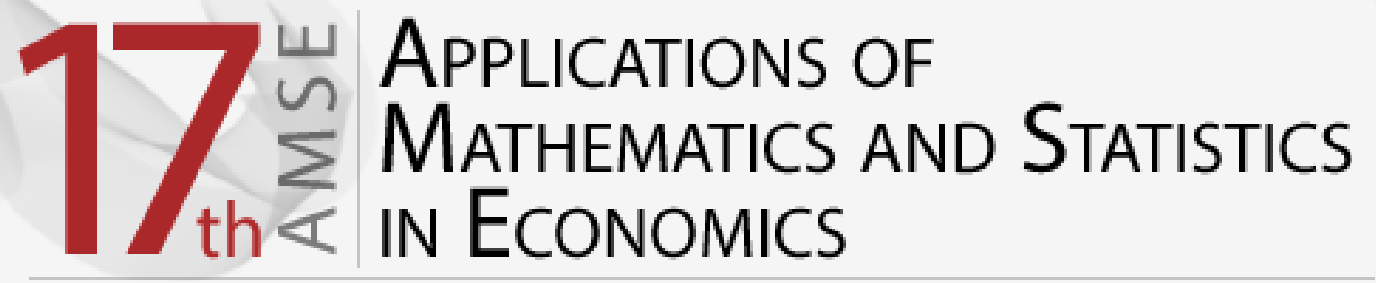

International Scientific Conference | Poland • 27-31 August 2014 
Scientific Committee

Richard Hindls, Stanislava Hronová, Rudolf Zimka, Walenty Ostasiewicz, Emília Zimková, Zofia Rusnak, Martin Bod'a

Organizing Committee

Beata Zmyślona, Cyprian Kozyra, Grzegorz Rogoziński, Kristýna Vltavská

\section{Reviewers}

Milan Bašta, Diana Bílková, Martin Bod'a, Joanna Dębicka, Tomáš Fiala, Jakub Fischer, Stanisław Heilpern, Karel Helman, Lenka Hudrlíková, Miroslav Hužvár, Nikola Kaspř́ková, Alena Kaščáková, Kamil Kladívko, Jindřich Klůfa, Pavol Král', Katarzyna Kuziak, Jana Langhamrová, Ivana Malá, Tomáš Marcinko, Luboš Marek, Miloš Maryška, Petr Mazouch, Zofia Mielecka-Kubień, Witold Miszczak, Petr Musil, Gabriela Nedelová, Walenty Ostasiewicz, Iva Pecáková, Viera Roháčová, Zofia Rusnak, Mária Stachová, Jana Špirková, Šárka Šustová, Jana Tepperová, Vladimír Úradníček, Kristýna Vltavská, Michal Vrabec, Dariusz Wawrzyniak, Henryk Zawadzki, Jaroslav Zbranek, Tomáš Zeithamer, Martin Zelený, Jan Zeman, Rudolf Zimka, Emília Zimková, Pavel Zimmermann, David Žižka

Layout

Martin Bod'a, Beata Zmyślona, Grzegorz Rogoziński

Front page design

Grzegorz Rogoziński

CD cover design

Beata Dębska

Articles published in the form submitted by the authors

All rights reserved. No part of this book may be reproduced in any form or in any means without the prior permission in writing of the Publisher

(C) Copyright by Wrocław University of Economics Wrocław 2014

ISBN 978-83-7695-421-9

Wydawnictwo Uniwersytetu Ekonomicznego we Wrocławiu

53-345 Wrocław, ul. Komandorska 118/120 www.ue.wroc.pl

Sprzedaż książek tel./fax 71 36-80-602

e-mail: econbook@ue.wroc.pl www.ksiegarnia.ue.wroc.pl 


\section{Contents}

Foreword

Diana Bílková: TL-Moments: Analogy of Classical L-Moments

Dagmar Blatná: Application of Robust Regression in the Analysis of Internet Access in European Countries

Martin Bod’a, Mária Kanderová: Rebalancing Issues in Tracking Error Variance Minimization

Martin Bod'a, Viera Roháčová: Application of Six Sigma Ideas to Timing Decisions at Financial Markets

Anton Dekrét, Rudolf Zimka: On the Price Hartwick's Task and Its Inverse in a Dynamic Model of an Economy with Exhaustible Resources

Joanna Dębicka, Agnieszka Marciniuk: Comparison of Reverse Annuity Contract and Reverse Mortgage on the Polish Market.

Petra Dotlačilová, Jitka Langhamrová: The Influence of Mortality Models for the Expected Future Life-time of Older People

Marek Ďurica, Lucia Švábová: Delta and Gamma for Chooser Options.

Vlastimil Farkašovský: New Concept of Pension Funds Performance Evaluation

Albert Gardon: The Normality of Weekly Relative Changes of the Freight Rate in Container Shipping.

Mária Grausová, Miroslav Hužvár, Jana Štrangfeldová: Healthcare Systems Efficiency in the Visegrád Group.

Stanisław Heilpern: Multiple Life Insurance - Pension Calculation

Alena Kaščáková, Gabriela Nedelová: Changes in Slovak Households' Economy

Igor Kollár, Pavol Král', Peter Laco: Methodology for Assessing Website Improvement in Corporate Environment.

Maciej Kostrzewski: Some Method of Detecting the Jump Clustering Phenomenon in Financial Time Series.

Cyprian Kozyra, Beata Zmyślona, Katarzyna Madziarska: Complementary Objective and Subjective Measures of Hospital Services Quality...

Pavol Král', Mária Stachová, Lukáš Sobíšek: Utilization of Repeatedly Measured Financial Ratios in Corporate Financial Distress Prediction in Slovakia

Ivana Malá: The Use of Finite Mixture Model for Describing Differences in Unemployment Duration

Lukáš Malec: Studying Economics and Tourism Industry Relations by Smooth Partial Least Squares Method Depending on Parameter. 
Tomáš Marcinko: Consequences of Assumption Violations Regarding Classical Location Tests.

Edyta Mazurek: The Income Tax Progression Depending on Social Insurance Contribution in Poland.

Petr Musil, Jana Kramulová, Jan Zeman: Regional Consumption Expenditures: An Important Starting Point for Regional Input-output Tables.

Katarzyna Ostasiewicz, Walenty Ostasiewicz: Good Life: From Political to Human Economy

Anna Sączewska-Piotrowska: Analysis of Poverty Transitions in Poland Using Multilevel Discrete-Time Event History Models

Martina Šimková, Petra Švarcová: Disadvantaged University Students in the Czech Republic.

Michal Široký: The Use of Short-term Business Statistics for Quarterly GDP Flash Estimates in the Czech Republic

Zdeněk Šulc, Hana Řezanková: Evaluation of Recent Similarity Measures for Categorical Data.

Lucia Švábová, Marek Ďurica: The Relationship Between the Finite Difference Method and Trinomial Trees

Kristýna Vltavská, Jaroslav Sixta: The Estimation of Final Consumption Expenditures

Lenka Vraná: Business Cycle Analysis: Tracking Turning Points

Janusz Wywiał: On Bayesian Testing in Auditing

Emília Zimková: Window Analysis of Supper-efficiency Change: Case of the Slovak Banking System ....

Beata Zmyślona: Statistical Modelling of the Impact of Diabetes on the Risk of Hospitalization 


\title{
THE NORMALITY OF WEEKLY RELATIVE CHANGES OF THE FREIGHT RATE IN CONTAINER SHIPPING
}

\author{
ALBERT GARDOŃ \\ Wroclaw University of Economics, Institute of Applied Mathematics, Chair of Statistics, \\ Komandorska 118/120, PL-53-345 Wrocław, POLAND \\ email: Albert.Gardon@ue.wroc.pl
}

\begin{abstract}
Models assuming the normality of real data are widely used in many disciplines, e.g. in finances, where the price processes are represented by the geometrical Brownian motion (Black-Scholes model). However, in last years this approach has been criticised because of the heavy tails of empirical data distributions which contradict the normality. The researchers have tried to overcome this problem creating models based on the so called jump-diffusion processes. Unfortunately, it has not helped either because the empirical data distributions, even after extraction of jumps, had significantly higher kurtosis than in the normal case.

In this paper we consider the normality of the average net freight tics from the s.c. Shanghai indeces and from one of the leading shipping lines and we have found out that also in this instance the empirical distributions differ from the gaussian one. But they are usually virtually normal except for only few large outliers. Therefore we applied the so-called threshold method for the identification of outliers and decided to treat them as jumps. It turned out that for remaining data the normality had been confirmed by all basic statistical tests, where even in the worst case the p-value had exceeded 10\%. Besides, the net freight tics were symetrical and centralized. This result opens the way for a proper application of gaussian models for the net freight behavior. Such models, similarly to the case of the financial market, could be used for predicting purposes and for the construction of hedging tools.
\end{abstract}

Key words: pricing and yield (revenue) management, liner shipping, data normality, jumpdiffusion, freight rate prediction models.

DOI: $10.15611 /$ amse.2014.17.10

\section{Preliminaries}

For the container shipping market the Herfindahl-Hirschman Index, which is a measure of industry concentration, remains below $7 \%$ (value between $1 \%$ and $15 \%$ indicates an unconcentrated industry) and the top 10 carriers have together only about $60 \%$ of the market share (see Alphaliner, 2012). That means the market is rather competitive. In such markets the psychology of many independent competitors plays a crucial role and hence, random models become adequate for describing the behavior of the market.

Models assuming the normality of real data are widely used in many disciplines, first and foremost in finances, where the price processes are represented by the geometrical Brownian motion (the famous Black-Scholes model - see Karatzas, Shreve, 1998). Unfortunately, in last years this purely gaussian approach has been criticized because of heavy tails of empirical 


\section{$12 \backsim$ APPLICATIONS OF

data distributions which contradict the normality (see Andersen, Bollerslev, Diebold, 2007; Cont, Tankov, 2004; Das, 2002; Johannes, 2004). However, the researchers have tried to overcome this problem by creating models based on the general jump-diffusion processes where large price changes have been extracted from the empirical distribution and modeled separately as jumps driven by the Poisson process. Differential equations describing such models must be usually solved by means of numerical methods (see Gardoń, 2004 and 2006). But it helps neither because the empirical distributions of a financial data, even after extraction of jumps, are asymmetrical or too slender, that means they have got significantly different skewness or higher kurtosis than in the normal case (see Gardoń, 2011; Peiró, 1999).

In this article we have verified if the container shipping data could be properly modeled in similar way to the financial markets data, i.e. by means of the linear jump-diffusion with an additional (in comparison to the standard Black-Scholes model) jump term driven by the homogeneous Poisson process with a certain intensity $\lambda$. The modeled process $X$ denotes in this instance the weekly average net freight (or rate, which is a transportation price consisting of basic ocean freight and different surcharges like e.g. fuel surcharge) per transported unit (TEU or FFE - the volume of a 20 or 40 feet long standard container). The equation mentioned has the following form:

$$
X_{t}=X_{t_{0}}+\int_{t_{0}}^{t} a X_{s} d s+\int_{t_{0}^{+}}^{t} b \bar{X}_{s} d W_{s}+\int_{t_{0}^{+}}^{t} \bar{C}_{s} \bar{X}_{s} d N_{s}, \quad t>t_{0}
$$

where $\bar{X}_{t}=X_{t^{-}}=\lim _{s \rightarrow t} X_{s}, W$ is a standardized Wiener process, $N$ is a homogeneous Poisson process with intensity $\lambda$ and the both driving processes are said to be independent. Coefficients $a, b$ and $\mathrm{C}$ (overlined $\mathrm{C}_{\mathrm{s}}$ means the left-hand side limit at $\mathrm{s}$, as for $\mathrm{X}$ ) are called here the drift, the volatility and the relative jump size, respectively. Further, $C$ denotes a strictly stationary process independent from the both driving processes $W$ and $N$ (see Mancini, 2009). This means the jump sizes are realizations of an independent identically distributed (iid) sequence of random variables $\left(C_{\Gamma_{i}}\right)$ which may be treated as independent copies of a certain random variable $C$, whereas the jump times of the process $N$ are denoted by $\left(\Gamma_{i}\right)$. Additionally, the sequence $\left(\tau_{n}\right)$ will represent times when the process is observed. There are several conditions which must be fulfilled for a proper application of such a model and will be checked in the following sections:

1. returns (called also tics or relative process changes) must be normally distributed ecsept for jump times if they exist (jump-diffusion), which will be verified in Sec.2;

2. returns must be independent from preceding process values (linearity), which will be verified in Sec.3;

3. interjump times, if they exist, must be exponentially iid (jump-diffusion driven by the homogeneous Poisson process), which will be verified in Sec.4.

\section{Normality of the container shipping data}

In our investigations we focused on the data from 16 Shanghai Containerized Freight Indices (SCFI) which describe the weekly average net freight for containers shipped from Shanghai to different parts of the world (see Chineseshipping, 2013). We decided to research this data because SCFI is the most popular index used for measuring the container market condition. The data set includes observations from the time period March 202009 to October 
19 2012, totally 186 tics. Additionally, we conducted the similar investigation for the weekly average net freight for the Company Overall (time period: January 82010 to May 6 2012, 121 tics) and for the Company Asia-Europe trade, head haul (main) direction (time period: January 22000 to August 5 2012, 656 tics) from one of the leading shipping lines. The results connected to the Company Asia-Europe trade are the most interesting. This trade is the most competitive and at the same time one of the most important for shipping lines in terms of a high amount of transported commodities.

The Black-Scholes model requires the discretized relative price changes:

$$
Z_{n}=\frac{X_{\tau_{n}}-X_{\tau_{n-1}}}{X_{\tau_{n-1}}}=\frac{\Delta X_{\tau_{n}}}{X_{\tau_{n-1}}} \approx \ln \frac{X_{\tau_{n}}}{X_{\tau_{n-1}}}, \quad n=1, \ldots, K,
$$

where $K$ is the number of observations, are realizations of a normally distributed random variables sequence. But since $\left(\tau_{n}\right)$ is not said to be equidistant the data must be firstly standardized:

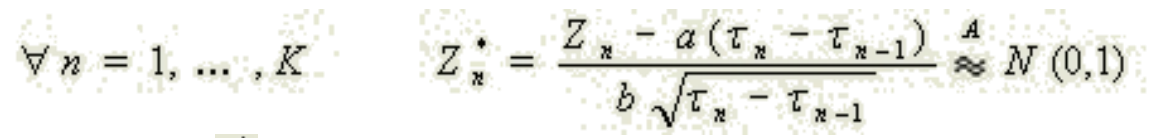

The symbol $\approx$ means the assymptotical distribution. Hence, the drift and volatility parameters $a$ and $b$ must be firstly estimated. However, the so-called no arbitrage assumption (see Karatzas, Shreve, 1998), insists on taking $a=\rho-\lambda E \boldsymbol{C}$ for the proper application of the jump-diffusion model (see Kou, 2002). The notation $\rho$ means a riskless rate. LIBOR is usually taken as $\rho$. On November 192012 this riskless rate was equal to $0.86 \%$ p.a. for 1 year USD contracts which implies for the time unit 1 week: $\rho=0,0165 \%$. On the contrary, the volatility may be estimated in the maximal likelihood sense by the standard deviation of normalized returns:

$$
\hat{b}=\sqrt{\frac{1}{K} \sum_{n=1}^{K} \frac{Z_{n}^{2}}{\Delta \tau_{n}}-\left(\frac{1}{K} \sum_{n=1}^{K} \frac{Z_{n}}{\sqrt{\Delta \tau_{n}}}\right)^{2}},
$$

which follows immediately from the fact, that the relative price changes $\left(Z_{n}\right)$ have to be normally distributed and $b$ is in such an instance the infinitesimal variance of the normalized return.

For the testing that $Z^{*} \sim N(0,1)$, where the iid standardized returns $\left(Z_{n}^{*}\right)$ are the independent copies of a certain random variable $Z^{*}$, we decided to use six basic statistical tests available in the statistical application R (see Thode, 2002): the Shapiro-Wilk test, the Shapiro-Francia test, the Anderson-Darling test, the Cramer-von Mises test, the Lilliefors test and the Pearson $\chi^{2}$ test. But the tests confirmed that none of the 18 data sets was normal. Only in two cases p-value exceeded $10^{-4}$ (Lilliefors and $\chi^{2}$ tests for Company Overall), but almost all of them were under $10^{-7}$. However, looking at the empirical distributions the data in most cases seemed to be normal except for a set of outliers as in Fig.1. That gave us a hope that after extraction of possible jumps these heavy tails could have been neglected and the remaining data would have been normal. Additionally, in several cases of SCFI we observed enormously high peak of the empirical density in the neighborhood of 0 . It turned out that it was caused by such weeks in which an index had not change. Theoretically, if the price was to 


\section{APPLICATIONS OF \\ Mathematics AND Statistics \\ IN ECONOMICS}

behave as a certain modification of the Brownian motion, it should not have been constant in any time interval. These null returns could have been the result of missing observations or index rounding because all indices but Comprehensive SCFI are represented by integers. For this reason we decided to omit all null returns, obviously, taking into account the increase of time span between some consecutive tics (where nulls removed). Usually there were approximately 10-20 unchanged observations in each SCFI data set, except only few cases: West Japan SCFI (72), East Japan SCFI (76), Southeast Asia SCFI (47), Korea SCFI (42) and Hong Kong SCFI (85).

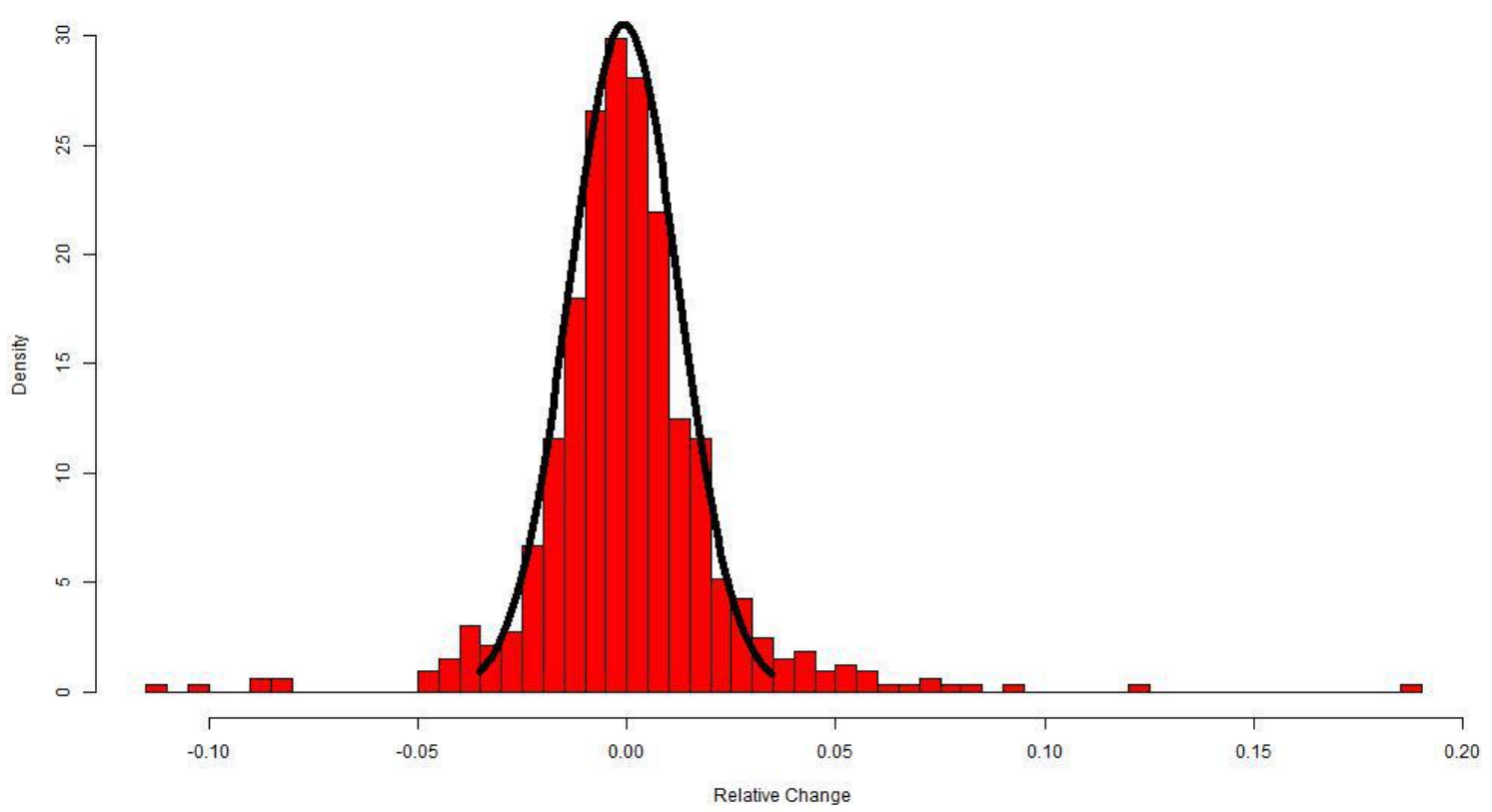

Figure 1. The normal vs empirical density of the relative rate changes for Company AsiaEurope trade.

Thus, the natural consequence of the result above was the need for identification of jumps. They could be recognized in several ways, but we decided to choose the so called threshold method presented by Mancini (2004 and 2009) and improved by Gardon (2011). This method consists in constructing the so-called threshold function $r$, which for each subinterval defines an upper limit for the process change. If the certain return is greater it is treated as a jump. Following Mancini (2009) and Gardon (2011) the threshold condition is:

$$
\frac{Z_{n}^{2}}{\wedge^{2}}>r\left(\Delta \tau_{n}\right),
$$

where $r(t)=\beta t^{1-\varepsilon}=7,3576 t^{0,9}$ and $\hat{b}$ is evaluated by means of an iterative procedure based on Eqn.(2) at each step. Thus, the set of data may be divided into two parts: the data representing continuous price changes and jumps. Applying the method we generally 
extracted 3-8 jumps yearly exept East Japan SCFI data where we have found 12 outliers. There was only a problem with Company Overall rates because there were only 3 jumps observed in over 2 years data.

The nulls removal and the jumps extraction improved significantly the data normality. The normality tests resulted in significantly higher p-values. In five cases we received the fully doubtless normality: Persian Gulf/Red Sea SCFI, where the minimal p-value equal to 0.066 was delivered by Lilliefors test, East/West Africa SCFI (0.048; Lilliefors), Taiwan SCFI (0.428; Lilliefors), Company Asia-Europe (0.09; Lilliefors) and Company Overall (0.129; Anderson-Darling). For South America SCFI only the Shapiro-Wilk and Shapiro-Francia tests resulted in $\mathrm{p}$-values a bit lower than $5 \%$, whereas other tests much over $10 \%$. Further, for Southeast Asia SCFI all tests were positive apart from the $\chi^{2}$ test, which was less reliable and gave $p \approx 10^{-5}$. Eventually, for East Japan SCFI all p-values were in the interval 1-5\%. The five worst cases included Europe SCFI, Australia/New Zealand SCFI, West Japan SCFI, Korea SCFI and Hong Kong SCFI, where p-values usually dropped below $10^{-4}$ for most tests.

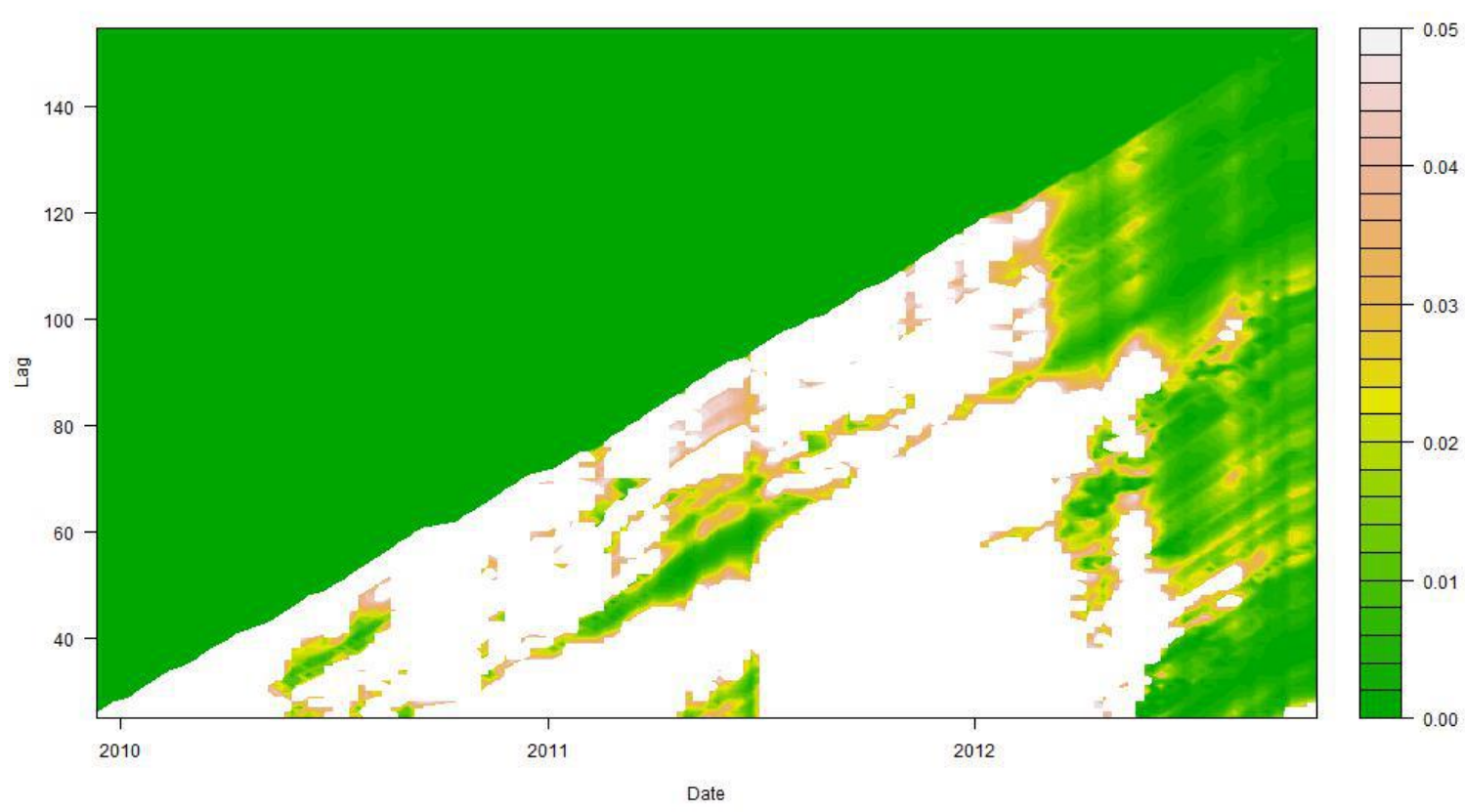

Figure 2. The evolution in time of the minimal p-value of 6 normality tests of South America SCFI data for different lags.

Nevertheless, our goal was to check how the normality depended on time lag and how it varied over time. We applied all normality tests again but this time for all possible time points. Besides, at each time point we checked the normality for different possible time lags, i.e. taking into account different numbers of past observations. Generally, apart from Europe SCFI, Australia/New Zealand SCFI, West Japan SCFI, Korea SCFI and Hong Kong SCFI the normality can be observed in all the remaining data sets for an appropriate choice of a time lag. The reader can see it e.g. in Fig.2. White regions denote minimal p-values over 5\% here. 
The upper triangle is actually an unavailable area because it requires the data from the time before the first year of the observation.. It is set to 0 just for the contrast to white regions at the diagonal. The results for Company Asia-Europe trade, which is the most important and competitive part of the shipping industry, are especially interesting. The normality has been confirmed for lags 150-300 and close to 600 (whole data set). It is a highly important result that the normality is so well fulfilled for this trade, because this one requires the highest attention in the business. It has been one of the most volatile in last years, moreover, the recent price war was especially visible there. The normality may make it possible to construct hedging strategies reducing profit fluctuations.

\section{Returns independence from the past}

In this section we check the second assumption from the linear jump-diffusion model (1) and namely if the normal tics $\left(Z_{n}^{c}\right)$ and the relative jump sizes $\left(C_{\tau_{n}}\right)$ are independent from the preceding process values $\left(X_{\tau_{n-1}}\right)$ and if the relative jump sizes $\left(C_{\tau_{n}}\right)$ are independent from the preceding interjump intervals $\left(\Delta \Gamma_{n-1}\right)$. The random sequence $\left(Z_{n}^{c}\right)$, in contradiction to $\left(Z_{n}^{*}\right)$ , denotes only "continuous" tics here, i.e. these ones not recognized as jumps. Of course, only those data sets were interesting for us in which we observed the normality.

Firstly, we devoted our attention to the tics from the continuous part testing if $Z_{n}^{c} \perp X_{\tau_{n-1}}$ . However, the $\chi^{2}$ independence test which is usually applied for the verification of such hypothesis requires the data ordered into a contingency table. Its results also depend on the choice of levels the data is ordered to. The test of correlation based on the $t$-Student distributed statistic should be more effiecient. Generally, it is a weaker property, but especially in the gaussian cases it gives good approximations of independence. Only in the case of Persian Gulf/Red Sea SCFI returns were significantly dependent on index values (pvalues of the correlation and the independence tests have been equal to 0.002 and 0.008 , respectively), but $R^{2}$ was only $6.2 \%$ which indicates only a slight correlation. In the instance of South Africa SCFI the correlation was not significantly different from $0(p=0.243)$, but the independence test failed a bit and its p-value dropped below $2 \%$. In all other instances $\mathrm{p}$ values of both tests were at least $8 \%$. We would like to add that in the most interesting case Company Asia-Europe trade - the $R^{2}$ was equal to $10^{-7}$. So, after this stage we concluded that all data sets with the verified normality but Persian Gulf/Red Sea SCFI were still appropriate for jump-diffusion modeling.

Next we dealt with the dependencies between jumps and previous process values testing if $C_{\tau_{n}} \perp X_{\tau_{n-1}}$. Since the numbers of jumps were rather small we decided to use the Fisher independence test for which the exact hypergeometric distribution of the test statistics is known. This test is very inefficient in the sense of the calculation time and memory usage but gives more exact results for a limited data. We conducted also the correlation tests. Only for East Japan SCFI the independence hypothesis should have been rejected $(p=0.005)$ but at least the correlation was still statistically insignificant. We also noticed that for Persian Gulf/Red Sea SCFI the correlation was significantly different from 0 with $R^{2}$ over $40 \%$ and p-value equal to $1 \%$, however, Persian Gulf/Red Sea SCFI also failed the previous independence test regarding preceding process values. In all other cases p-values exceeded 
$15 \%$ apart from Company Overall where the test could have not been conducted because of 3 jumps observed in this data set only.

Our last research in this section concerns the dependencies between jump sizes $\left(C_{\tau_{n}}\right)$ and preceding interjump period lengths $\left(\Delta \Gamma_{n-1}\right)$ verified by means of the Fisher test for the same reason as before. As we already know the investigation could not have been conducted for Company Overall because of too few jumps. Among the remaining data sets only for South America SCFI the independence null-hypothesis had to be rejected with p-value equal to 0.004. In this case $R^{2}=19 \%$ differed significantly from 0 as well with $p=0.033$. Besides, in two other cases, for Southeast Asia SCFI and again for Persian Gulf/Red Sea SCFI, $R^{2}$ was significantly positive (63\% and $36 \%$, respectively) with p-value below $2 \%$ in both cases.

\section{Intensity and distribution of jumps}

In this section we verify the distribution of the interjump period lengths. If the discontinuous part of the jump diffusion equation was to be driven by the homogeneous Poisson process of intensity $\lambda$, then it should hold $\Delta \Gamma \sim \operatorname{Exp}(\lambda)$, where the lengths of interjump intervals $\left(\Delta \Gamma_{i}\right)$ are the independent copies of a certain random variable $\Delta \Gamma$. We used the Kolmogorov-Smirnov test. Only in the case of East Japan SCFI the result was negative ( $p=0.005$ ). Actually, for almost all data the $\mathrm{p}$-value was greater than $50 \%$ and only for Company Asia-Europe it exceeded slightly the sufficient 5\% level ( $p=5.6 \%$ ). However, the problem is this test requires at least a 50 elements sample to be reliable, which is fulfilled only by Company Asia-Europe trade data set containing the observations from over 12 years. Therefore we decided to check additionally all cases visually by means of QQ-plots. This verification was rather satisfactory. Only on the right-hand side of the graphs we observed usually 1-2 outliers. A virtually worse goodness-of-fit was noticed only for US West Coast SCFI.

Additionally, the interjump period lengths should be also realizations of a sequence of independent random variables. It is difficult to give a satisfactory proof for the validity of this assumption but in order to have any knowledge of this property we calculated the autocorrelation function values for interjump lags for all data sets. Summing up the results of this investigation we can state that we observed a slightly significant autocorrelation only for East Japan SCFI and moreover, only in one instance - for the 6 jumps shift. But we already discovered another problem about this index namely with interjump period lengths inconsistent with the exponential distribution. For all other indices the autocorrelation was always insignificant and for about a half of the data sets, including the most interesting Company Asia-Europe trade, $R^{2}$ never exceeded even the 5\% level.

\section{Predictive model}

Actually, the forecasting is not the main application of models based on the jump-diffusion but it is also possible to use them for such a purpose. We conducted similar investigations for all data sets for which the assumptions from the model (1) were valid. The chosen time horizons were $1,4,6,8$ weeks and 3 months. The exact prediction in such models is just the actual process value multiplied by the riskless interest rate factor, which is equal to the future expected value of such processes. One can see an example of such a forcast in Fig.3. The 


\section{7. \\ Mathematics AND Statistics \\ the IN ECONOMICS}

additional limits of the $90 \%$-confidence interval for the 6 -weeks prediction were usually \pm 5 $10 \%$ about the expectation.

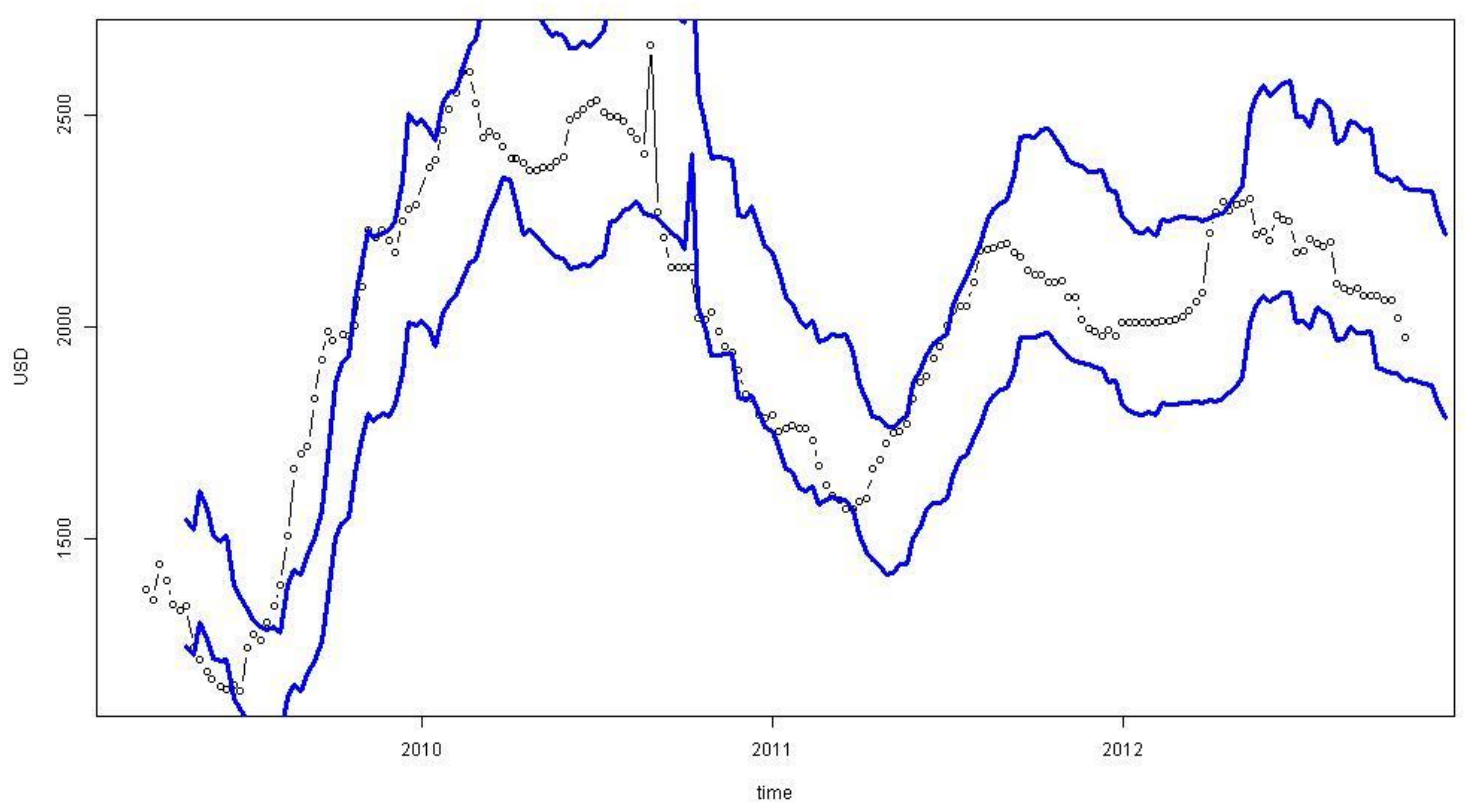

Figure 3. The actual value of East/West Africa SCFI and the $90 \%$ confidence interval for its 6-weeks forecast.

\section{Conclusions}

The original Black-Scholes model cannot be applied for modeling freight rates or index trajectories because of deviation from normality. But generally, for the majority of data sets investigated, both SCFI and a chosen company internal data, the linear Poissonian jumpdiffusion model (1) should give a good approximation, except for the following exceptions:

- any jump-diffusion model for Europe SCFI, Australia/New Zealand SCFI, West Japan SCFI, Korea SCFI and Hong Kong SCFI must not be applied because returns are not normally distributed in these instances even after the extraction of outliers;

- the jump part for Company Overall could not be investigated because only 3 jumps appeared, thus, its proper calibration was impossible;

- regarding Persian Gulf/Red Sea SCFI rather a general nonlinear jump-diffusion should be considered because a recent process value affects significantly a consecutive return;

- the model for East Japan SCFI should be driven by another counting process rather than the Poissonian one because interjump period lengths were non-exponentially distributed and after 6 jumps slightly autocorrelated; moreover, the jump coefficient should be rather nonlinear because a recent process value affects significantly a consecutive jump size.

On the contrary, the linear Poissonian jump-diffusion model should be very accurate especially for East/West Africa SCFI, Taiwan SCFI and Company Asia-Europe trade. 
However, a proper size of time lag in several remained cases should be chosen for calibration of the model.

The results mean that generally the jump-diffusion model may be properly applied in the container shipping, especially in such market parts where the historical data is properly rich. Fortunately, this is the case of the most competitive and thereby the most essential AsiaEurope trade. The research lets provide the hedging tools similar to those from the financial markets, as e.g. Call options (see Karatzas, Shreve, 1998)to the container shipping. The investigation is conducted basing on the data from a chosen company only, though, since this part of the market is significantly competitive, the competitors' freight rates should be quite similar to one another. Thus, the results may be applied by each company operating in this field.

\section{Acknowledgements}

This research was funded by the Danish Maritime Fund, through grant no. 2011-58.

\section{References}

1. ALPHALINER, 2012. Weekly Newsletter, No. 41.

2. ANDERSEN, T., BOLlERSLEV, T., DIEBOLD F. , 2007. Roughing It Up: Including Jump Components in the Measurement, Modeling and Forecasting of Return Volatility. Review of Economics and Statistics 89, pp. 701-720.

3. CHINESESHIPPING, 2013. http://www1.chineseshipping.com.cn.

4. CONT, R., TANKOV, P. , 2004. Financial Modelling with Jump Processes. Chapman \& Hall - CRC.

5. DAS, S. , 2002. The Surprise Element: Jumps in Interest Rates. Journal of Econometrics 106, pp. 27-65.

6. GARDON, A. , 2004. The Order of Approximations for Solutions of Itô -type Stochastic Differential Equations with Jumps. Stochastic Analysis and Applications, Vol. 22, No. 3, pp. 679-699.

7. GARDOŃ, A. , 2006. The Order 1.5 Approximations for Solutions of Jump-Diffusion Equations. Stochastic Analysis and Applications, Vol. 24, No. 6, pp. 1147-1168.

8. GARDOŃ, A. , 2011. The Normality of the Financial Data after an Extraction of Jumps in the Jump-Diffusion Model. Mathematical Economics, Vol.14, No. 7, pp. 79-92.

9. JOHANNES, M. , 2004. The Statistical and Economic Role of Jumps in Continuous-time Interest Rate Models. Journal of Finance 59, pp. 227-260.

10. KARATZAS, I., SHREVE, S. E. , 1998. Methods of Mathematical Finance. SpringerVerlag, New York.

11. KOU, S.G. , 2002. A Jump-Diffusion Model for Option Pricing. Management Science 48, pp. 1086-1101.

12. MANCINI, C. , 2004. Estimation of the Parameters of Jump of a General PoissonDiffusion Model. Scandinavian Actuarial Journal 1, pp. 42-52.

13. MANCINI, C. , 2009. Non Parametric Threshold Estimation for Models with Stochastic Diffusion Coefficient and Jumps. Scandinavian Journal of Statistics, Vol. 36, Iss. 2, pp. 270-296.

14. PEIRÓ, A. , 1999. Skewness in Financial Returns. Journal of Banking and Finance, Vol. 23, Iss. 6, pp. 847-862.

15. THODE, H.C.JR., 2002. Testing for Normality. Marcel Dekker, New York. 